\title{
Colonization of bare rock surfaces by microflora in a rocky intertidal habitat
}

\author{
John H. MacLulich \\ Zoology Building, School of Biological Sciences, University of Sydney, N.S.W. 2006, Australia
}

\begin{abstract}
The rapid colonization by microscopic plants of natural bare rock surfaces in an intertidal habitat was investigated. The sequence of colonization (from bacteria, to diatoms to blue-green algae and spores of macroalgae) was illustrated by scanning electron micrographs. The endpoint assemblage was characterised by the blue-green alga Anacystis sp., and a number of diatoms and spores. The rapid speed of recovery to the endpoint community (within $4 \mathrm{wk}$ ) and the nature of the community itself differed from those described in similar habitats, possibly as a result of the grazing regime at the site studied.
\end{abstract}

\section{INTRODUCTION}

Many investigations have been made of recolonization and secondary succession in rocky intertidal habitats, most considering the regrowth of macroalgae (Emerson \& Zedler 1978, Foster 1978, Murray \& Littler 1978, Southward \& Southward 1978, Sousa 1979 , Underwood 1980, Underwood \& Jernakoff 1981, 1984, and earlier papers reviewed by Connell 1972). Most of these studies have described a sequence of colonization that proceeds from bacteria and diatoms to ephemeral green or brown algae and then to perennial red and brown algae. In doing so, most have only briefly mentioned the early colonization of bare spaces by such forms as bacteria and diatoms, and have concentrated their discussions upon later events. Other studies have made mention of early colonizers in the process of studying seasonal events (Castenholz 1963, 1967). The lack of information regarding the sequence of colonization of microscopic forms is probably a result of the more difficult methods required for their study (MacLulich unpubl.).

Studies of colonization by microflora in habitats other than on intertidal rock platforms are not much more common. Hoagland et al. (1982) investigated the sequence of colonization of freshwater periphyton on perspex and glass, making abundant use of the scanning electron microscope (SEM). Hudon \& Bourget (1982) have described the initial colonization on plastic sheets in subtidal and intertidal estuarine habitats, also using the SEM. Belanger \& Cardinal (1977) observed the development of microfloral populations on glass slides, while Weise \& Rheinheimer (1978) investigated the bacterial and diatom colonization of sand grains from an intertidal beach. None of these workers has made use of natural rock surfaces as substrata.

In this paper are described the results of an experiment to test the hypothesis that rock surfaces in an intertidal habitat will return to their original state after disturbance. This hypothesis was supported, and descriptive information about the initial colonization of natural rock surfaces by microflora was obtained.

\section{METHODS}

The study site, within the Brisbane Water National Park, was located some $100 \mathrm{~m}$ south of the headland at Green Point, $35 \mathrm{~km}$ north of Sydney, N.S.W., Australia. The intertidal biota of this area has been described by Underwood (1981). A smoothly sloping, even surface approximately $4 \times 8 \mathrm{~m}$ was chosen at the mid- to hightide level (1.0 to $1.5 \mathrm{~m}$ above the low-tide datum for Sydney). The area was almost $100 \%$ bare sandstone, with a small number of limpets (Cellana tramoserica [Sowerby] 6 ind $\mathrm{m}^{-2}$ ) and snails (Littorina unifasciata Gray; 5 to 10 ind $\mathrm{m}^{-2}$ ) and a patchy cover of the barnacle Tesseropera rosea (Krauss) at the lower margin. No foliose or encrusting macro-algae were present in the $4 \times 8 \mathrm{~m}$ study area.

Two sets of samples were collected over a period of 
$34 \mathrm{~d}$ in late autumn, when the weather was generally sunny but cold $\left(10\right.$ to $\left.17^{\circ} \mathrm{C}\right)$, and the seas were calm: (1) samples from control (untouched) areas; (2) samples from initially cleared, bare surfaces. Twenty-five randomiy chosen $10 \times 10 \mathrm{~cm}$ areas within the study area were completely cleared of all growths by grinding the rock surface with an abrasive disc fitted to an electric drill, powered by a portable generator. This process removed up to $5 \mathrm{~mm}$ of the surface rock, exposing a new, clean surface. At approximately weekly intervals, samples were taken from each of 5 of these cleared areas (selected randomly from the 25) and from each of 5 nearby, untouched areas (chosen at random). From each $10 \times 10 \mathrm{~cm}$ area, 2 samples of rock (approximately $1 \times 1 \times 0.5 \mathrm{~cm}$ ) were chipped from the surface using a hammer and chisel. These rock chips were dried in air, coated with gold or platinum and observed using a Jeol 35C scanning electron microscope. Photographs of representative types of microflora were taken.

Also from each $10 \times 10 \mathrm{~cm}$ area, 2 samples were obtained by the 'toothbrushing' technique (Stockner \& Armstrong 1971, Nicotri 1977, MacLulich unpubl.). A $5 \times 5 \mathrm{~cm}$ area of the rock surface was moistened with seawater and then scrubbed with a toothbrush. The slurry which accumulated on the toothbrush was washed into a specimen tube, to which a few drops of $37 \%$ formaldehyde had been added. The scrubbing was repeated until no further material appeared to be removed from the rock. Samples obtained in this way were examined with a light microscope at $400 \times$, using phase contrast. A subsample was removed from each specimen tube and transferred to a haemocytometer slide and the total numbers of all taxa of microfloral cells were recorded. The density of each taxon was calculated and the number of taxa in each sample (hereinafter referred to as diversity) was recorded. These data were subjected to analyses of variance and Student-Newman-Keuls tests to reveal differences and similarities between control and experimental samples.

All microfloral taxa except bacteria were identified to generic level. Scanning electron micrographs were used extensively for this purpose, especially for the identification of diatoms. For statistical analyses, the taxa were divided into 3 groups, representing the 3 most abundant types of cells - bacteria, diatoms and the blue-green alga Anacystis sp.

A total period of $5 \mathrm{wk}$ was chosen for this experiment because earlier observations (Underwood 1984) indicated that within $4 \mathrm{wk}$ bare rock surfaces at this tidal height regain the appearance of surrounding regions. In order to confirm this, 10 randomly selected areas within the study site were cleared approximately $4 \mathrm{wk}$ before regular sampling began: these were sampled at the start of the experiment ( $4 \mathrm{wk}$ later). The microfloral populations in these samples were compared with those in 10 samples from randomly chosen, nearby, untouched areas: no significant differences, in either density or diversity of microalgae, were observed (analyses of variance, Table 1). Although the present study extended over only $5 \mathrm{wk}$, there is evidence to suggest that the community observed after this short time is not different from that observed after 2 yr (Underwood 1980, Underwood \& Jernakoff 1981, 1984, Jernakoff 1983). The term 'endpoint' community can therefore be applied to these microfloral populations.

\section{RESULTS}

The rate of increase in density of total cells was initially rapid, but slowed, reaching zero after $4 \mathrm{wk}$ (Fig. 1A). The densities of cells in samples taken on Days 0,3 and 15 were significantly smaller than the densities of cells taken from control areas, but thereafter no significant differences between such samples were evident (Table 2). The densities of cells in the control samples exhibited only slight fluctuations and remained almost constant (Fig. 1A).

The diversity in each sample increased rapidly during the first $3 \mathrm{wk}$, at a reasonably constant rate, until, by the 22nd day, no difference was detectable between control and experimental samples, and the rate of increase was virtually zero (Fig. 2 and associated analysis of variance in Table 3 ).

A large amount of detrital material was evident within $1 \mathrm{~d}$ of clearing (Fig. 3A) and after $3 \mathrm{~d}$ a signifi-

Table 1. Results of 1 -factor analyses of variance in (A) density and (B) diversity of the microfloral assemblage between control areas (Day 0) and areas that had been cleared $27 \mathrm{~d}$ previously. In both analyses, variances were homogeneous; Cochran's test, $\mathrm{P}>0.05$. In all tables: ns: non-significant, $\mathrm{P}>0.05 ;{ }^{\circ}$ significant, $\mathrm{P}<0.05 ; \cdots$ highly significant, $\mathrm{P}<0.01$

\begin{tabular}{|ccccc|}
\hline $\begin{array}{c}\text { Source of } \\
\text { variance }\end{array}$ & $\begin{array}{c}\text { Degrees of } \\
\text { freedom }\end{array}$ & Mean square & Fratio & Mean square \\
\hline $\begin{array}{c}\text { Between days } \\
\text { Within days }\end{array}$ & 1 & 0.03 & $0.02^{\text {ns }}$ & 4.90 \\
\hline
\end{tabular}



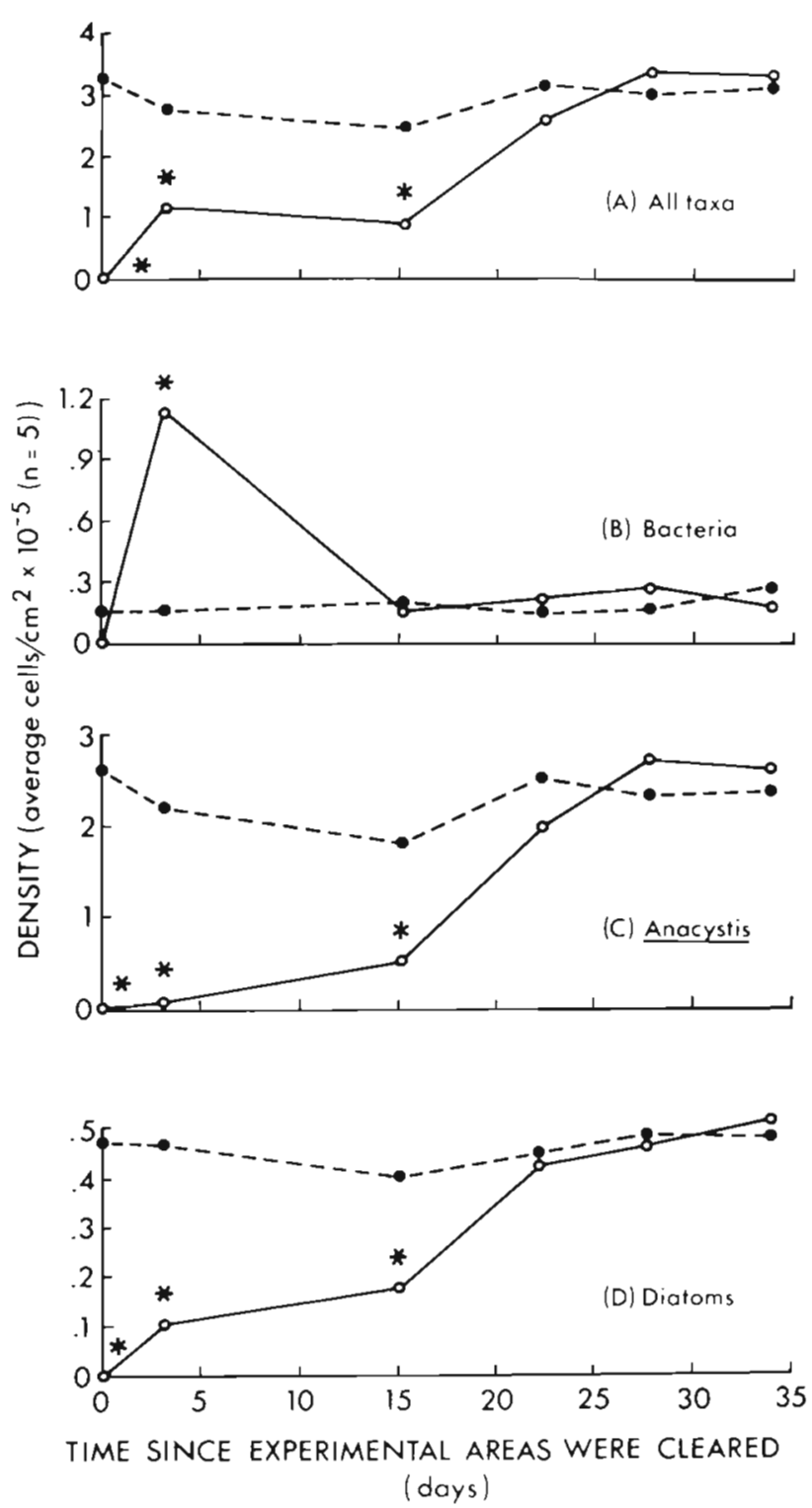

Fig. 1. Changes in density of components of the microfloral assemblage in control ( ) and cleared (O) areas. Analyses of variance of the data used to construct these graphs are given in Table 2. (*) Treatment means significantly different from their respective control means (Student-Newman-Keuls tests). Pooled SEs for all means are (A) 0.43 ; (B) 0.13 ; (C) 0.42 ; (D) 0.04 cells $\mathrm{cm}^{-2} \times 10^{-5}$ cant cover of bacteria had developed (Fig. 1B \& 3B). By the 15 th day, this population of bacteria was reduced to the level found in the control samples (Fig. 1B). At this stage, some transient diatom species (e.g. Pinnularia sp., Nitzschia sp. and Licmophora sp.) had become established (Fig. 3C) and the dominant blue-green alga Anacystis sp., was evident (Fig. 1C \& 3D). By the 22nd day, the population of Anacystis sp. had increased to the level found in control samples and a somewhat different assemblage of diatoms was apparent (e.g. Coscinodiscus sp., Cocconeis sp., Navicula sp. and Achnanthes sp.) (Fig. 3E). After $27 \mathrm{~d}$, multicellular forms were distinguishable and some macroalgal spores were noticed (Fig. 3F, G, H). At this stage the assemblage of diatoms was not different from that of the control samples.

\section{DISCUSSION}

The above results demonstrate that, in the presence of grazers, patches of rock at Green Point returned to a state indistinguishable from surrounding untouched

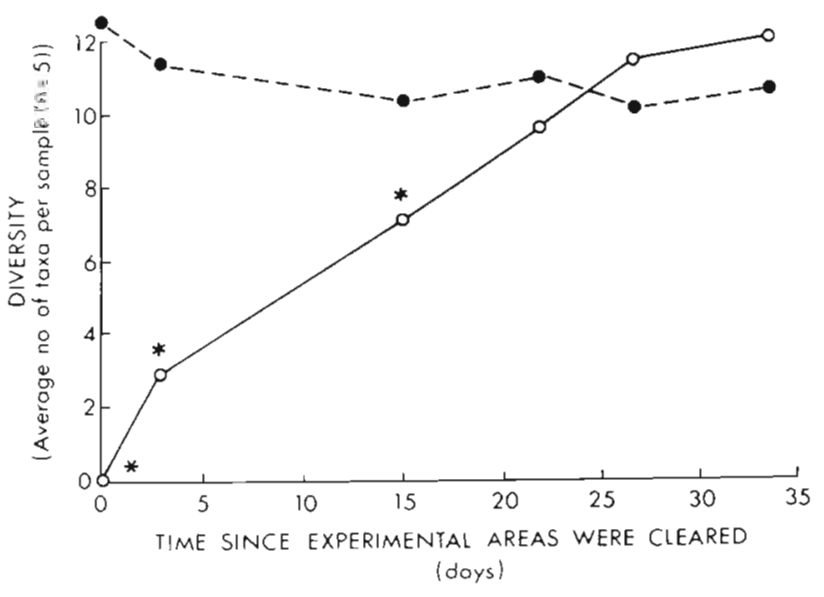

Fig. 2. Changes in diversity of the microfloral assemblage in control ( $\bullet$ ) and cleared (o) areas. Analysis of variance of the data used to construct the graph is given in Table 3 . (*) Treatment means significantly different from their respective control means (Student-Newman-Keuls tests). Pooled SE for all means is 0.97 taxa sample ${ }^{-1}$

Table 2. Results of 2-factor analyses of variance of difference in density of each component of the microfloral assemblage, between control and cleared areas. For each analysis, variances were homogeneous; Cochran's test, P>0.05

\begin{tabular}{|c|c|c|c|c|c|c|c|c|c|}
\hline \multirow[b]{2}{*}{$\begin{array}{l}\text { Source } \\
\text { of variance }\end{array}$} & \multirow[b]{2}{*}{$\begin{array}{l}\text { Degrees } \\
\text { of freedom }\end{array}$} & \multicolumn{2}{|c|}{ (A) All taxa } & \multicolumn{2}{|c|}{ (B) Bacteria } & \multicolumn{2}{|c|}{ (C) Anacystis } & \multicolumn{2}{|c|}{ (D) Diatoms } \\
\hline & & $\begin{array}{l}\text { Mean } \\
\text { square }\end{array}$ & F ratio & $\begin{array}{l}\text { Mean } \\
\text { square }\end{array}$ & F ratio & $\begin{array}{l}\text { Mean } \\
\text { square }\end{array}$ & F ratio & $\begin{array}{l}\text { Mean } \\
\text { square }\end{array}$ & F ratio \\
\hline Treatment & 1 & 17.63 & $18.9^{\cdots}$ & 0.25 & $3.3^{\mathrm{ns}}$ & 16.08 & $18.3^{*}$ & 0.49 & $78.2 \cdots$ \\
\hline Time & 5 & 5.00 & $5.4^{\cdots}$ & 0.39 & $5.3 \cdots$ & 4.32 & $4.9^{\cdots}$ & 0.11 & $17.0^{\circ}$ \\
\hline Treatment $\times$ time & 5 & 4.61 & $5.0^{\cdots}$ & 0.42 & $5.5^{\cdots}$ & 3.72 & $4.2^{\cdots}$ & 0.12 & $18.7^{\cdots}$ \\
\hline Residual & 48 & 0.93 & & 0.08 & & 0.88 & & 0.01 & \\
\hline
\end{tabular}




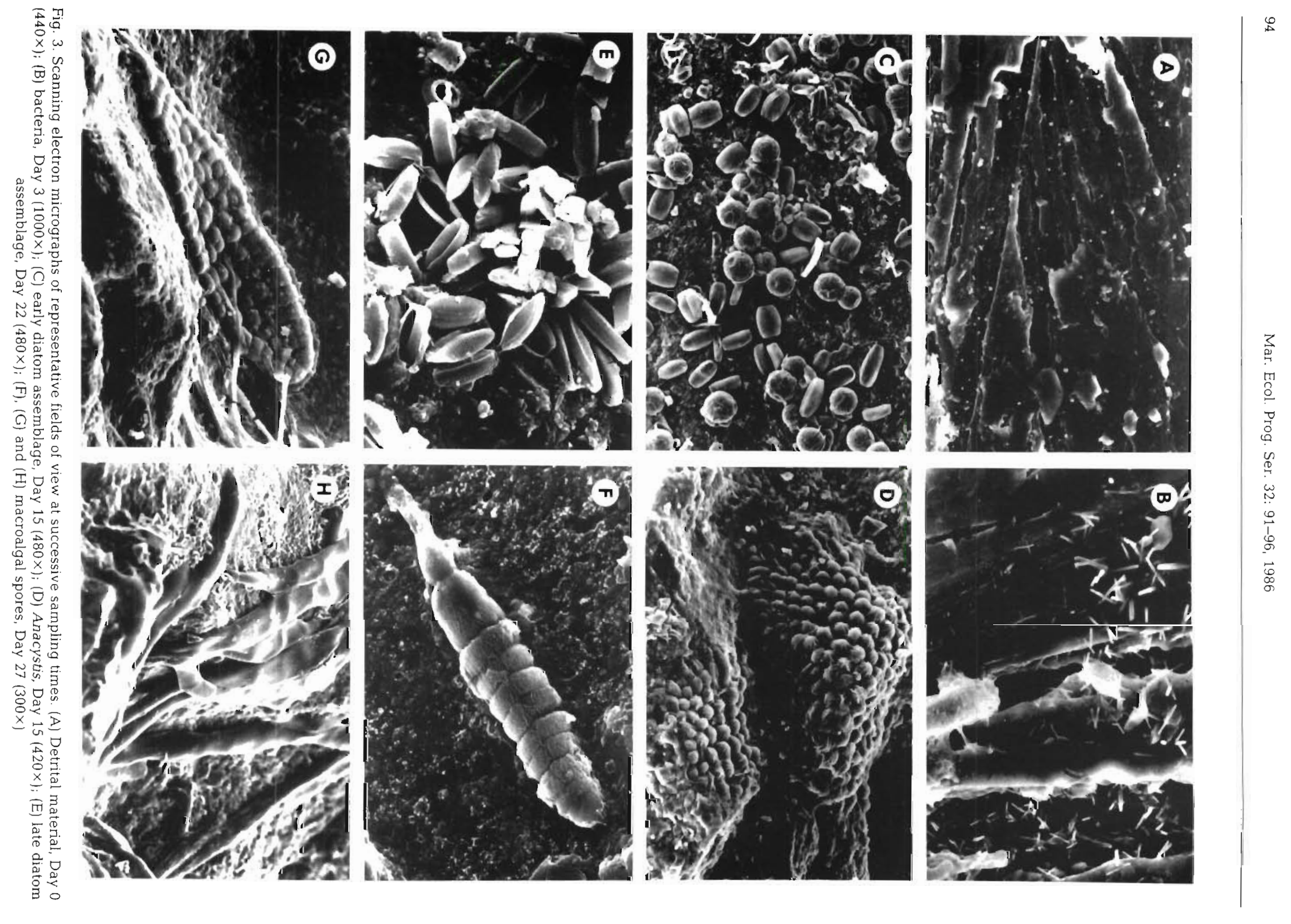


Table 3. Results of 2-factor analysis of variance of difference in diversity of the microfloral assemblage between control and previously cleared areas. Variances were homogeneous; Cochran's test, P $>0.05$

\begin{tabular}{lcrr|}
\hline Source of variance & Degrees of freedom & Mean square & F ratio \\
\hline Treatment & 1 & 205.4 & 44.0 \\
Time & 5 & 42.3 & 9.1 \\
Treatment $\times$ time & 5 & 1979.8 & 17.0 \\
Residual & 48 & 4.7 & $\cdots$ \\
\hline
\end{tabular}

areas within 4 wk of clearing (a state that can be referred to as an 'endpoint') and that this state was an assemblage characterised by the blue-green alga Anacystis sp., and a number of diatom species and spores of macro-algae.

Such a situation does not appear to have been described before. It may be unique, both in terms of the rate of recovery and of the nature of the endpoint. Green Point is located in a warm, temperate latitude, in which the growth of algae can be very rapid. Previous studies of the colonization of microflora in situations other than in intertidal epilithic habitats have revealed that the recovery to the endpoint community can take anything from 8 to 22 wk (Hoagland et al. 1982). In intertidal habitats, recovery times have been typically greater than 2 yr (Guiler 1954, Dayton 1971. Murray \& Littler 1978).

The situation at Green Point appears to be an 'arrested succession'. The substratum is highly grazed and the grazers are known to prevent the establishment of a macroalgal climax community above lowtide levels. Repeated experiments (Underwood 1980, Underwood \& Jernakoff 1981, 1984, Jernakoff 1983) have shown that only in the absence of grazers will a macroalgal turf develop. It is likely that the grazing herbivores prevent the succession from proceeding beyond a relatively early stage by preventing colonization of some species. This appears to fit the model of disturbance effects on successional events outlined by Connell (1975).

Connell \& Slatyer (1977) outlined and defined mechanisms of succession and detailed 3 alternative models which could determine the sequence of species: these are the 'facilitation' model, the 'tolerance' model and the 'inhibition' model. No evidence, however, can be found to determine which model may be more appropriate at Green Point. There is no evidence available from this experiment, for example, that early colonizers (bacteria) modify the environment either to the advantage or disadvantage of subsequent species. Further study is called for, but experimental manipulations to test the hypotheses proposed by Connell \& Slatyer would be difficult to investigate in such a microscopic situation. Future investigations should give more attention to identification of the microflora and should be made at other sites and at other times of the year, as significant temporal and spatial variations in the density and diversity of the microfloral assemblage are known to exist (MacLulich 1983).

Acknowledgements. I thank Dr. A. J. Underwood for his advice and helpful comments throughout this study, Dr. R. G. Creese for comments on the manuscript, and the staff of the Electron Microscope Unit at the University of Sydney for their assistance in obtaining micrographs. The research described here formed part of the requirements for the degree of $\mathrm{M}$. Sc. in the Department of Zoology, University of Sydney.

\section{LITERATURE CITED}

Belanger, C., Cardinal, A. (1977). Stades initiaux de colonisation de substrats durs dans la Baie des Chaleurs, Quebec. Mar. Biol. 44: 27-38

Castenholz, R. W. (1963). An experimental study of the vertical distribution of littoral marine diatoms. Limnol. Oceanogr. 8: 450-462

Castenholz, R. W. (1967). Seasonal ecology of non-planktonic marine diatoms on the western coast of Norway. Sarsia 29: $237-256$

Connell, J. H. (1972). Community interactions on marine rocky intertidal shores. Ann. Rev. Ecol. Syst. 3: 169-192

Connell, J. H. (1975). Some mechanisms producing structure in natural communities: a model and evidence from field experiments. In: Cody, M. L., Diamond, J. M. (ed.) Ecology and evolution of communities. Harvard Belknap Press, Cambridge, Massachusetts, p. 460-490

Connell, J. H., Slatyer, R. O. (1977). Mechanisms of succession in natural communities and their role in community stability and organization. Am. Nat. 111: 1119-1144

Dayton, P. K. (1971). Competition, disturbance and community organisation: the provision and subsequent utilisation of space in a rocky intertidal community. Ecol. Monogr. 41: 351-389

Emerson, S. E., Zedler, J. B. (1978). Recolonization of intertidal algae: an experimental study. Mar. Biol. 44: 315-324

Foster, M. S. (1978). Factors controlling the zonation of Iridaea flaccida (Rhodophyta). J. Phycol. 18: 285-294

Guiler, E. R. (1954). The recolonization of rock surfaces and the problem of succession. Pap. Proc. Roy. Soc. Tasmania 88: 49-66

Hoagland, K. D., Roemer, S. C., Rosowski, J. R. (1982). Colonization and community structure of two periphyton assemblages, with emphasis on the diatoms (Bacillariophyceae). Am. J. Bot. 69: 188-213

Hudon, C., Bourget, E. (1981). Initial colonization of artificial substrate: community development and structure studied 
by scanning electron microscopy. Can. J. Fish. Aquat. Sci. 38: $1371-1384$

Jernakoff, P. (1983). Factors affecting the recruitment of algae in a midshore region dominated by barnacles. J. exp. mar Biol. Ecol. 67: 17-31

MacLulich, J. H. (1983). Aspects of the ecology of intertidal, epilithic microflora at Green Point, New South Wales. M. Sc. thesis, Univ. of Sydney

Murray, S. N., Littler, M. M. (1978). Patterns of algal succession in a perturbated marine intertidal community. J. Phycol. 14: 506-512

Nicotri, M. E. (1977). Grazing effects of four marine intertidal herbivores on the microflora. Ecology 58: 1020-1032

Sousa, W. P. (1979). Experimental investigations of disturbance and ecological succession in a rocky intertidal community. Ecol. Monogr. 49: 227-254

Southward, A. J., Southward, E. C. (1978). Recolonization of rocky shores in Cornwall after use of toxic dispersants to clean up the Torrey Canyon oil spill. J. Fish. Res. Bd Can. 35: $682-706$

Stockner, J. G., Armstrong, F. A. J. (1971). Periphyton of the experimental lakes area, northwest Ontario. J. Fish. Res. Bd Can. 28: 215-229
Underwood, A. J. (1980). The effects of grazing by gastropods and physical factors on the upper limit of distribution of intertidal macroalgae. Oecologia (Berl.) 46: 201-213

Underwood, A. J. (1981). Structure of a rocky intertidal community in New South Wales: patterns of vertical distribution and seasonal changes. J. exp. mar. Biol. Ecol. 51: $57-85$

Underwood, A. J. (1984). The vertical distribution and seasonal abundance of microalgae on a rocky shore in New South Wales. J. exp. mar. Biol. Ecol. 78: 199-220

Underwood, A. J., Jernakoff, P. (1981). Effects of interactions between algae and grazing gastropods on the structure of a low-shore intertidal algal community, Oecologia (Berl.) 48: 221-233

Underwood, A. J., Jemakoff, P. (1984). The effects of tidal height, wave exposure, seasonality and rock-pools on grazing and the distribution of intertidal macroalgae in New South Wales. J. exp. mar. Biol. Ecol. 75: 71-96

Weise, W., Rheinheimer, G. (1978). Scanning electron microscopy and epifluorescence investigation of bacterial colonization of marine sand sediments. Microb. Ecol. 4: $175-188$

This article was presented by Professor J. S. Pearse; it was accepted for printing on May 29, 1986 